\title{
Long-Term Monitoring of Treatment with Recombinant Human Growth Hormone by Serial Determinations of Type III Procollagen-Related Antigens in Serum
}

\author{
THOMAS DANNE, ANNETTE GRÜTERS, KERSTIN SCHNABEL, WALTER BURGER, \\ DAGMAR L'ALLEMAND, INGO ENDERS, HANS HELGE, AND BRUNO WEBER
}

Free University Children's Clinic, Klinikum Charlottenburg, West Berlin, Federal Republic of Germany

\begin{abstract}
Inasmuch as recombinant human growth hormone is now more generally available for the treatment of different types of short stature, there is a need for better short-term indicators of treatment success. In healthy children, serum concentrations of antigens related to the aminoterminal propeptide of type III procollagen (P-III-NP) closely follow the growth velocity curve. P-III-NP was measured longitudinally in $\mathbf{2 0}$ children with growth hormone deficiency during 6 months of human growth hormone substitution therapy. Two different radioimmunoassay systems were used; one recognizes predominantly the intact propeptide showing a lesser affinity to a smaller monomeric peptide (RIAgnost assay), while the other assay detects both forms equally (FAB assay). These results were compared to the growth response [median $5.6(0.4$ to 13.9) $\mathrm{cm}$ in 6 months] and to other established growth correlated parameters (somatomedin $C$, alkaline phosphatase). A relatively better growth response correlated significantly with high pretreatment P-III-NP (RIAgnost assay) values $(r=0.56)$ and delayed bone age $(r=-0.70)$. A combination of these parameters in multiple regression analysis increased the cumulative prediction value to above $60 \%\left(r^{2}=0.61\right)$. On the other hand, P-III-NP (FAB assay) values proved to be best in monitoring treatment, correlating with the individual growth rate during the first 3 months $(r=0.40 ; p<0.05)$, during the consecutive 3 months $(r=$ $0.66 ; p<0.001)$, and during the total 6 -months period $(r$ $=0.46 ; p<0.05$ ). All other parameters showed associations to growth only during some treatment periods. Ease of measurement and good correlation with the growth response support the use of the P-III-NP determination in monitoring of human growth hormone therapy. (Pediatr Res 23: 167-171, 1988)
\end{abstract}

\section{Abbreviations}

hGH, human growth hormone

r-hGH, recombinant hGH

GHD, growth hormone deficiency

P-III-NP, amino-terminal procollagen type III propeptide

RIAgnost, radioimmunoassay for P-III-NP using complete antibodies against $P$-III-NP

FAB, radioimmunoassay for P-III-NP using Fab antibody fragments against P-III-NP

Received May 11, 1987; accepted September 29, 1987.

Correspondence and reprint requests, Dr. Thomas Danne, Kinderklinik der Freien Universität Berlin, Kaiserin Auguste Viktoria Haus, Heubnerweg 6, 1000 Berlin 19, Federal Republic of Germany. Th.D. is supported by a postdoctoral grant of Deutsche Forschungsgemeinschaft.
SMC, somatomedin C

AP, alkaline phosphatase

SDS-BA, standard deviation score for standing height calculated according to bone age

SDS-CA, standard deviation score for standing height calculated according to chronological age

SPSS, Statistical Package for the Social Sciences

Short stature caused by inadequate secretion of pituitary hGH can be successfully treated by substitution with recombinant $\mathrm{hGH}$ which now is available in almost unlimited amounts for therapeutic use (1). Numerous children with various forms of short stature are currently enrolled in clinical trials of hGH therapy (2), and factors predictive of $\mathrm{hGH}$ responsiveness as well as indicators of treatment success are being sought. Established parameters for short term monitoring of hGH therapy, i.e. somatomedin $C(3,4)$ and alkaline phosphatase $(5)$, often fail to correlate with growth. Measurements of height change give reliable results only after several months of treatment.

As collagen is the most important protein constituent of the extracellular matrix, collagen generation must be a prerequisite for normal growth. Precursor-specific segments of type-III procollagen, the major interstitial collagen, are cleaved in stoichiometric amounts during fibrillogenesis and various molecular species of the P-III-NP are released into serum (6-8). Recently developed radioimmunoassay systems (9-11) allow study of the concentrations of these peptides in human body fluids during health and disease. When determined by molecular exclusion chromatography and radioimmunoassay, the intact triple stranded procollagen type III peptide (Col 1-3) and a smaller monomeric fragment ( $\mathrm{Col} 1$ ) represent the major P-III-NP serum antigens during growth (12). In childhood P-III-NP levels vary with age $(13,14)$ correlating significantly with the growth velocity curve (15). The possible use of P-III-NP measurements for the assessment of growth-related changes has been proposed recently (15-17). We investigated 20 children with GHD before and during the first 6 months of treatment with recombinant hGH to elucidate the value of P-III-NP determinations compared to other well-established parameters, for predicting therapeutic success and for monitoring growth during hGH therapy.

\section{MATERIALS AND METHODS}

Patients. Twenty GHD children (11 male, nine female) were investigated after written informed consent was given by their parents. Auxological data before treatment is summarized in Table 1. Thirteen patients had been treated previously with 
Table 1. Auxological data before treatment*

\begin{tabular}{lrc}
\hline Age (yr) & 9.6 & $(5.1-19.2)$ \\
Bone age retardation (yr) & 2.6 & $(0-8)$ \\
Length (SDS-CA) & -2.8 & $(-0.7-4.5)$ \\
Length (SDS-BA) & 1.9 & $(-3.4-4.2)$ \\
Wt (kg) & 25.7 & $(11.0-58.0)$ \\
Growth velocity before treat- & 3.4 & $(0.2-7.1)$ \\
$\quad$ ment (cm/yr) & & \\
\hline
\end{tabular}

* Median (range).

extracted hGH, but hGH therapy had been withdrawn after the risk of transmission of Creutzfeldt-Jacob's disease (18) became known. Seven patients were newly diagnosed.

Eight patients had complete and three had partial isolated idiopathic GHD; seven had multiple pituitary hormone deficiencies due to organic lesions, one had an empty-sella syndrome, and one had postradiation GHD. Patients with GHD after craniopharyngeoma were excluded from this study. Eleven patients with accompanying thyroid-stimulating hormone deficiencies and seven with partial ACTH deficiencies had received proper replacement therapy before the initiation of the study. Seventeen patients were prepubertal [stage I according to Tanner $(19,20)$ ], two were pubertal (stage III, and IV, respectively), and one was fully mature (stage V).

Diagnosis of $G H D$. The diagnosis of GHD was made by demonstrating an inadequate hGH response after 1) administration of hGH-releasing factor (1-44) $(1 \mu \mathrm{g} / \mathrm{kg}$ body weight, $n=$ $20), 2)$ arginine infusion $(0.5 \mathrm{~g} / \mathrm{kg}$ body weight, $n=14)$, and 3$)$ insulin-induced hypoglycemia $(0.1 \mathrm{IU} / \mathrm{kg}$ body weight, $n=18)$. Basal serum $\mathrm{hGH}$ and somatomedin $\mathrm{C}$ levels were measured before treatment at 30-min intervals for $4 \mathrm{~h}$ during deep sleep and additionally every $2 \mathrm{~h}$ for a total of $24 \mathrm{~h}(n=20)$. Complete GHD was diagnosed when hGH values did not exceed $5 \mathrm{ng} / \mathrm{ml}$ in any of these tests (except the GRF test). The three patients with partial GHD had an abnormal response in two tests but a spontaneous hGH secretion in the low normal range during $6 \mathrm{~h}$ of deep sleep (expressed as integral under the curve, according to Bierich (21); more than $2000 \mathrm{ng} \times \min \times \mathrm{ml}^{-1}$ ). These patients also exhibited the highest basal SMC values and pretreatment growth rates. Exclusion of these three patients from the data analysis did not change the results.

r-hGH from one of three different sources (Norditropin, Nordisk, Gentofte, Denmark, $n=14 ; \mathrm{r}-\mathrm{hGH}$, Kabi-Vitrum, Munich, FRG, $n=3$; Somatropin, Eli Lilly, Bad Homburg, FRG, $n=3$ ) was administered by one daily subcutaneous injection of $2 \mathrm{IU} /$ $\mathrm{m}^{2}$ body surface at bedtime for 6 or 7 days/wk.

Standing height was measured with a stadiometer (Holtain Ltd., Crymmich, England). Heights and growth velocities were expressed as SDS according to Tanner et al. (22) and related to SDS-BA to permit comparisons in children with different stages of maturity. Bone age was determined by $x$-ray of the right wrist by the standards of Greulich and Pyle (22a).

Laboratory methods. Radioimmunoassays for serum P-III-NP were performed with two different assays. One was a commercially available antibody radioimmunoassay (RIAgnost) (RIAgnost P-III-P, Behringwerke AG, Marburg, FRG). Antibodies used in this kit recognize the intact propeptide (Col 1-3) and exhibit a 10 -fold lesser affinity to Col 1 peptides $(8,10)$. In addition we used a research version (generously supplied by Behringwerke $A G$ ) of this kit (FAB) using monovalent Fab antibody fragments that are equally reactive with Col $1-3$ and Col 1 fragments (10). The intrassay variation for the RIAgnost assay was $11 \%$ and for the Fab modification was $6 \%$. The respective interassay variations were 15 and $7 \%$. Sensitivity of the RIAgnost assay was about $0.5 \mathrm{ng} / \mathrm{ml}$ and that of the FAB assay was about $5 \mathrm{ng} / \mathrm{ml}$. Cross-reactivity of antibodies with other collagen types or fragments [type I procollagen, type I collagen, type IV collagen ( $\mathrm{NC1}$ and $7 \mathrm{~S}$ domains)], or with
Laminin P1 was less than $1 \%$. Normal values are correlated to growth; values more than $40 \mathrm{ng} / \mathrm{ml}$ (RIAgnost) or $180 \mathrm{ng} / \mathrm{ml}$ (FAB) are seen occasionally in tall children during puberty (15). In adults values range between 3 to 13 and 9 to $97 \mathrm{ng} / \mathrm{ml}$, respectively (23).

Serum hGH concentrations were determined by radioimmunoassay as described by Quabbe (24). SMC was measured in unextracted sera by a commercial kit (Nichols Institute Diagnostics, San Juan Capistrano, CA). AP was determined with a kinetic assay (Roche, Grenzach, FRG).

Statistical analysis. Statistical analysis was performed using the SPSS (25) with the Spearman correlation coefficient and the Mann-Whitney rank sum test. A multivariate regression analysis was used to define those variables exerting influences independent of others. This procedure also allowed the calculation of the relative importance (percent of overall predictive value) of the individual variables for predicting the increase in SDS-BA after 6 months. The total of 20 patients allows the evaluation of the predictivity of two variables showing the highest correlation.

\section{P-III-NP (RIAgnost)}

$\mathrm{ng} / \mathrm{ml}$

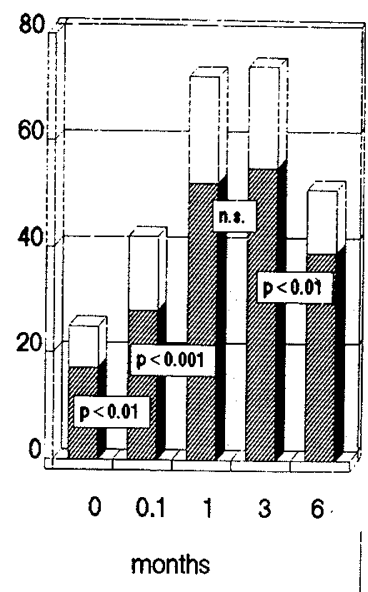

Somatomedin C

$\mathrm{U} / \mathrm{ml}$

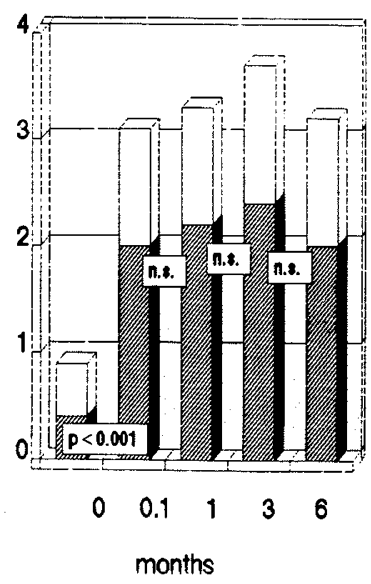

P - III - NP (FAB)

$\mathrm{ng} / \mathrm{ml}$

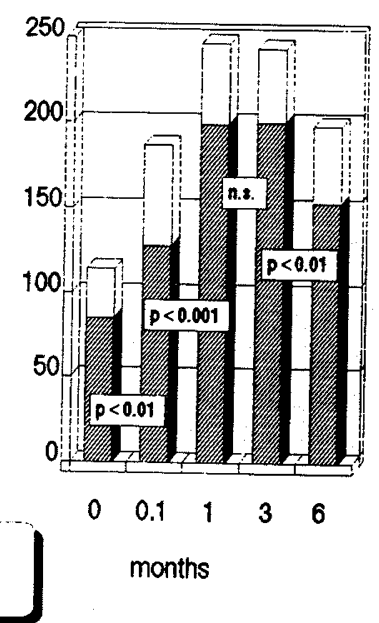

Alkaline Phosphatase

$\mathrm{U} / \mathrm{I}$

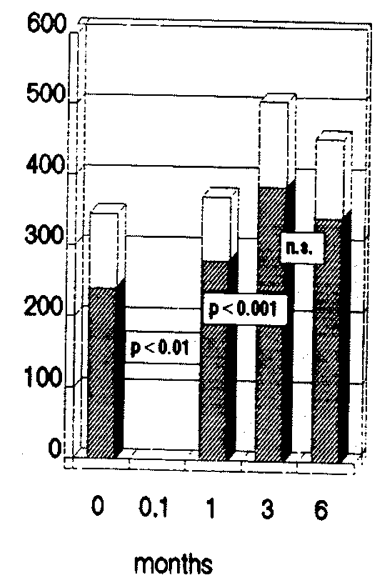

Fig. 1. Mean values (and 1 SD) of the several monitoring parameters during treatment. Statistical differences between two consecutive measurements are indicated. AP was not determined after 3 days of treatment. All parameters showed significant increases with treatment. Corresponding to the lower median growth rate during the second treatment period P-III-NP values (RIAgnost and FAB) decline significantly after 3 months of treatment while no significant decreases were seen in SMC and AP. 


\section{RESULTS}

Growth data. After 6 months of hGH treatment, patients showed increases in body height between 0.4 and $13.9 \mathrm{~cm}$ (median $5.6 \mathrm{~cm}$ ) and an improvement in the SDS score for body length between 0.07 and 2.1 (median 0.93 ) for SDS-CA, and from 0.07 to 2.3 (median 1.03) for SDS-BA. Median growth was better during the initial 3 months $[3.6(0.3-3.2) \mathrm{cm}]$ than in the following period $[2.3(0.1-4.9) \mathrm{cm}]$.

No differences were observed between patients with different types of GHD or receiving different preparations of hGH. Sexual maturation or residual hGH secretion did not show a clear influence on growth response. The median growth was calculated to be $5.8 \mathrm{~cm}$ in the subgroups of the 17 prepubertal as well as in the 17 patients with complete GHD. In patients with partial GHD the two prepubertal patients showed average responses (4.9 and $5.8 \mathrm{~cm}$ ) while the one patient in puberty (stage III, bone age $14.5 \mathrm{yr}$ ) did not grow $(0.4 \mathrm{~cm})$. The growth responses of another pubertal patient (stage IV, bone age $14 \mathrm{yr} ; 6.7 \mathrm{~cm}$ growth) and the sexually mature patient (stage $\mathrm{V}$, bone age $16 \mathrm{yr} ; 1.3 \mathrm{~cm}$ growth) with complete GHD were adequate regarding their growth potential.

Biochemical data. Significant increases of P-III-NP and SMC levels were seen after 3 days $(p<0.01)$ (Fig. 1). While a further increase after 1 month was seen for P-III-NP $(p<0.01)$ to values above those usually seen in healthy children, no further significant increase of SMC was observed. Although the individual courses varied, no mean rises were observed after 3 months except for AP. Levels of all parameters declined thereafter, correlating with the mean growth rate. P-III-NP values obtained with either assay correlated significantly with each other at all times during the course of treatment ( $r$ values were $0.85,0.92$, $0.61,0.80,0.79$ at $0,0.1,1,3$, and 6 months).

Predictability of growth rate. Of those parameters determined before onset of therapy (Table 2), only two proved to be associated with height increase after 6 months of therapy and seemed to have predictive relevance. Lower skeletal age $(r=-0.70, p<$ 0.01 ) as well as higher P-III-NP (RIAgnost method) before therapy correlated with better growth $(r=0.56 ; p<0.05)$ (Fig. 2). All variables listed in Table 2 were included in a multiple regression analysis to study their eventual independent predictive value for growth as measured by the SDS-BA. While skeletal age exhibited the highest correlation, basal P-III-NP (RIAgnost) values prove to be the second most important variable independent from skeletal age. Combination of skeletal age and P-III-NP (RIAgnost) concentrations before therapy increases the correlation to growth rate (multiple $r=0.80$ ). The cumulative prediction value rises above $60 \%\left(r^{2}=0.614\right)$. However, neither the initial increases of P-III-NP values (FAB or RIAgnost) after 3 days and 1 month nor measurements of SMC or AP correlated with growth after 6 months.

Biochemical monitoring of hGH treatment. To investigate the use of P-III-NP (RIAgnost), P-III-NP (FAB), SMC, and AP serum determinations to monitor treatment, the values were correlated with growth in the respective intervals between determinations (i.e. first and second 3 months). While basal P-III-NP (RIAgnost) levels seemed to have predictive value, those determined with the FAB method proved to be the better parameter for monitoring the success of hGH treatment. FAB serum levels correlated significantly with growth rate during the first 3-month period $(r$ $=0.40, p<0.05)$, the consecutive 3 months $(r=0.66, p<0.01)$, or the total 6-month period $(r=0.46, p<0.05)$. Other parameters showed a good correlation only during some periods: AP ( $r=$

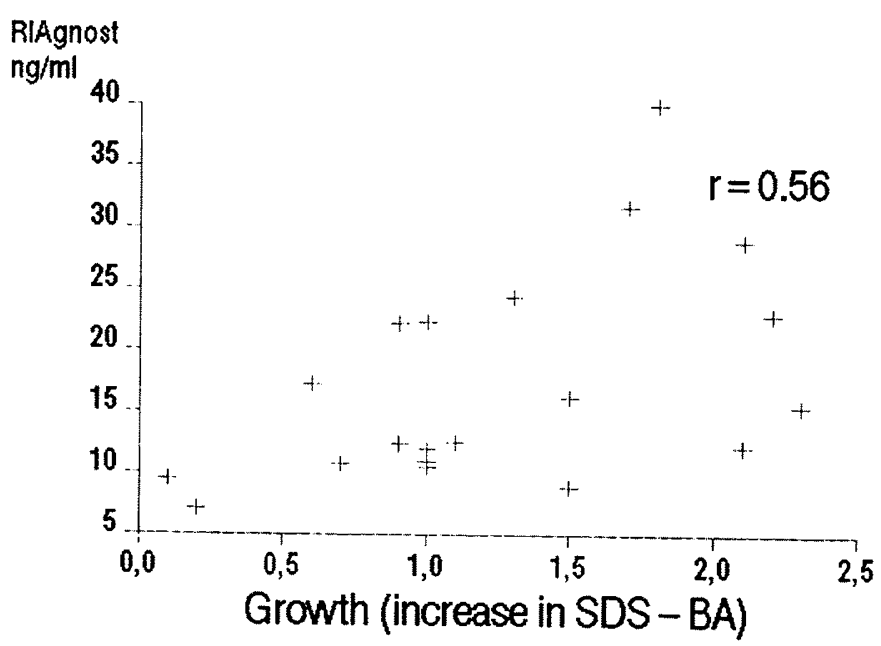

Fig. 2. Correlation between pretreatment P-III-NP values (RIAgnost method) and growth (expressed as improvement in the SDS-BA during 6 months of hGH treatment. Basal P-III-NP values correlated significantly $(p<0.05)$ with growth response. P-III-NP values determined with the FAB method showed no significant correlation $(r=0.27)$.

Table 2. Parameters before treatment and correlation with growth after 6 months

\begin{tabular}{|c|c|c|c|c|c|}
\hline \multirow[b]{2}{*}{ Parameter } & \multicolumn{2}{|c|}{$\begin{array}{l}\text { Pretreatment } \\
\text { value }\end{array}$} & \multicolumn{3}{|c|}{$\begin{array}{l}\text { Correlation with growth } \\
\text { after } 6 \text { mo ( } r \text { values) }\end{array}$} \\
\hline & Median & (Range) & $\mathrm{cm}$ & $\begin{array}{c}\text { Increase } \\
\text { in SDS-CA }\end{array}$ & $\begin{array}{c}\text { Increase } \\
\text { in SDS-BA }\end{array}$ \\
\hline Bone age $(\mathrm{yr})$ & 7.2 & $(1.6-15.1)$ & $-0.40 \dagger$ & $-0.50 \dagger$ & $-0.70 \ddagger$ \\
\hline $\begin{array}{l}\text { Growth velocity before therapy } \\
(\mathrm{cm} / \mathrm{yr})\end{array}$ & 3.4 & $(0.2-7.1)$ & -0.36 & -0.25 & -0.06 \\
\hline $\begin{array}{l}\text { Max. hGH level after arginine stimu- } \\
\text { lation }(\mathrm{ng} / \mathrm{ml})\end{array}$ & 1.0 & $(0.5-4.5)$ & 0.07 & 0.11 & 0.18 \\
\hline $\begin{array}{l}\text { Spontaneous hGH secretion during } \\
\text { deep sleep (integral under curve } \\
\left(\mathrm{ng} \cdot \mathrm{min} \cdot \mathrm{ml}^{-1}\right)\end{array}$ & 350 & $(180-3875)$ & -0.03 & -0.07 & 0.14 \\
\hline $\begin{array}{l}\text { Max. hGH level after GRF stimula- } \\
\text { tion (ng/ml) }\end{array}$ & 7.1 & $(0.5-47)$ & -0.01 & -0.03 & 0.15 \\
\hline $\mathrm{SMC}(\mathrm{U} / \mathrm{ml})$ & 0.2 & $(0.1-2.0)$ & -0.30 & -0.25 & -0.06 \\
\hline $\operatorname{AP}(\mathrm{U} / \mathrm{l})$ & 199 & $(92-498)$ & $0.42 \dagger$ & 0.37 & 0.36 \\
\hline P-III-NP (RIAgnost) (ng/ml) & 12.5 & $(7.1-40.0)$ & $0.51 \dagger$ & $0.56 \dagger$ & $0.56 \dagger$ \\
\hline P-III-NP (FAB) (ng/ml) & 73 & $(49-139)$ & 0.29 & 0.32 & 0.27 \\
\hline
\end{tabular}

* The correlation of with growth, expressed as increase in height in $\mathrm{cm}$ or corrected for chronological age (SDS-CA) and bone age (SDS-BA), is listed as the value for the correlation coefficient $r$.

Significant correlations which might indicate a prognostic value of this determination are marked $(\dagger p<0.05, \ddagger p<0.01)$. 
$0.66,0$ to 3 months; $r=0.28,3$ to 6 months; $r=0.50,0$ to 6 months); P-III-NP (RIAgnost) $(r=0.28,0.41$, and 0.22$)$; and $\operatorname{SMC}(r-0.33,-0.48$, and -0.36$)$.

\section{DISCUSSION}

This study demonstrates that in GHD those patients with the most marked delay in bone maturation and those with normal collagen synthesis (as assessed by normal basal P-III-NP levels) may profit most from hGH treatment. Bone growth takes place in cartilagineous tissue but increased synthesis of supporting tissues also is necessary with type III collagen being the major interstitial collagen. Although type III collagen is absent in fully calcified bone it reappears during bone remodeling (26). Therefore, determination of P-III-NP may give information about the activity of the connective tissue during growth. During situations of supernormal hGH secretion as in acromegaly (27) or of increased bone turnover as in Paget's disease (28), adults exhibit elevated P-III-NP levels. These increased values return to normal during successful treatment $(27,28)$.

P-III-NP serum antigens can be determined by two different methods. Although RIAgnost and FAB values correlate with each other, the methods give different information. The RIAgnost method recognizes predominantly the intact propeptide (Col 1-3) and may be more sensitive than FAB in reflecting unstimulated basal collagen metabolism. The good positive correlation between normal P-III-NP (RIAgnost) values before treatment and subsequent growth during treatment indicates that reasonably normal collagen synthesis may be a prerequisite for a satisfactory growth response to hGH. This is important in view of the fact that treatment with hGH is proposed also for diseases in which disturbances of connective tissue or bone metabolism are suspected (e.g. Turner's syndrome) (29). Indeed low basal levels of P-III-NP are found in many patients with Turner's syndrome (15) suggesting, according to the above hypothesis, a poor growth response despite an eventually increased growth velocity at the onset of therapy (30).

Carey et al. (31) assumed that high baseline values of type I procollagen in GHD predict a less than optimal response to growth hormone. These differences might be attributed to the fact that three of Carey's patients, with low basal type I procollagen values and good growth responses, suffered from organic hypopituitarism due to craniopharyngiomata. Such patients, for unknown reasons, may show good growth independent of hGH substitution (33). Furthermore, there was no correlation of basal type I procollagen levels with growth in 12 patients $(r=-0.06)$, and normal values for type I procollagen or the relation of values to growth velocity in healthy children have not been determined.

On the other hand, we found, in accordance with Carey's observation, that treatment with hGH leads to a rise of serum collagen peptides that antedates measurable changes in body length. For better interpretation of results the exact relationship of these peptides to collagen synthesis and degradation have to be elucidated. The stimulation of collagen synthesis during hGH treatment is associated with increases in levels of type I (31), type III $(12,16)$, and type IV (unpublished data) procollagen fractions in serum. P-III-NP immunoreactivity in serum increases most rapidly due to increases in both the intact propeptide (Col 1-3), which is related to fibrillogenesis, and a smaller fragment (Col 1) (12). The FAB method detects both fragments equally and this may explain the better correlation of FAB serum levels with the hGH treatment response compared to results with the RIAgnost assay.

The good correlation of P-III-NP levels to the clinical response to $\mathrm{hGH}$ therapy suggests that the routine use of these assays for monitoring treatment with $\mathrm{r}-\mathrm{hGH}$ may be useful. Up to now neither one of the presently available biochemical parameters alone nor the increase in growth velocity is totally reliable in predicting the success of hGH treatment after the short term. Therefore, a combination of parameters as shown herein for P-
III-NP and bone age may help to identify those patients likely to profit from hGH treatment.

Acknowledgments. The authors thank Mrs. Marja Hasala, Mrs. Marion Weiner, and Mrs. Magret Streich for their invaluable assistance in patient care and sample collection. Furthermore we acknowledge the help of Mrs. Bettina Tippel, Mrs. Dürten Dörfeldt, Mrs. Gabriela Betzoldt, and Mr. Bernd Berger for technical assistance in routine laboratory determinations and Mr. Reinhard Hartmann with statistical evaluation.

\section{REFERENCES}

1. Bierich JR, Ranke MB, Beyer P, Borkenstein H, Brämswig J, Butenandt $O$, Kollmann F, Stöver B, Schweickert HU, Schönberg KD, Heinrich U, Sippell W, Stahnke N, Stubbe P, Ziegler R 1986 Treatment of pituitary dwarfism with recombinant human growth hormone: a multi-centre study. Dtsch Med Wochenschr 111:483-489

2. Preece MA 1986 Biosynthetic growth hormone: whom to treat? $\mathrm{Br}$ Med $\mathrm{J}$ 293:1185-1186

3. Plotnick LP, van Meter QL, Kowarski AA 1983 Human growth hormone treatment of children with growth failure and normal growth hormone levels by immunoassay: lack of correlation with somatomedin generation. Pediatrics 71:324-327

4. Rosenfeld RG, Kemp SF, Hintz RL 1981 Constancy of somatomedin response to growth hormone treatment in hypopituitary dwarfism and lack of correlation with growth rate. J Clin Endocrinol Metab 53: 611-616

5. Butenandt O 1983 Metabolic effects of growth hormone in growth-hormone deficient children. In: Ranke MB, Bierich J (eds) Growth Hormone Deficiency. Urban \& Schwarzenberg, Baltimore, pp 68-77

6. Prockop DJ, Kivirikko KI, Tuderman L, Guzman A 1979 The biosynthesis of collagen and its disorders. N Engl J Med 301:13-23, 77-85

7. Nowack H, Olsen BR, Timpl R 1976 Characterisation of the amino-terminal segment in type III procollagen. Eur J Biochem 70:205-216

8. Rohde H, Bruckner P, Timpl R 1983 Immunochemical properties of the aminopropeptide of procollagen type III. Eur J Biochem 135:197-202

9. Rohde H, Vargas L, Hahn E, Kalbfleisch H, Bruguera M, Timpl R 1979 Radioimmunoassay for type III procollagen peptide and its application to human liver disease. Eur J Clin Invest 9:451-459

10. Rohde H, Langer I, Krieg T, Timpl R 1983 Serum and urine analysis of the amino-terminal procollagen peptide type III by radioimmunoassay with antibody fab fragments. Coll Relat Res 3:371-379

11. Pierard D, Nusgens V, Lapiere CH M 1984 Radioimmunoassay for the aminoterminal sequences of type III procollagen in human body fluids measuring fragmented precursor frequences. Anal Biochem 141:127-136

12. Danne Th, Grüters A, l'Allemand D, Schuppan D, Weber B, Hahn EG 1987 Rapid monitoring of growth hormone treatment by serum determinations of type III procollagen-related antigens. Eur J Pediatr 146:98

13. Trivedi P, Cheeseman P, Portmann B, Hegarty J, Mowat AP 1985 Variation in serum type III procollagen peptide with age in healthy subjects and its comparative value in the assessment of disease activity in children and adults with chronic active hepatitis. Eur J Clin Invest 15:69-74

14. Trivedi P, Cheeseman P, Portmann B, Mowat AP 1986 Serum type III procollagen peptide as a non-invasive marker of liver damage during infancy and childhood in extrahepatic biliary atresia, idiopathic hepatitis of infancy and $\alpha 1$ antitrypsin deficiency. Clin Chim Acta 161:137-146

15. Danne Th, Grüters A, Quandas N, Betzoldt G, Enders I, Charissis G, Weber B 1987 Serum procollagen type III propeptide reflects somatic growth in healthy children and patients with growth disorders. Endocrinol Invest 10(suppl 4):73

16. Lindstedt G, Weijkum L, Lundberg PA 1984 Serum procollagen-III as indicator of therapeutic effect in children treated for somatropin deficiency. Clin Chem 30:1879-1880

17. Trivedi P, Hindmarsh P, Stanhope R, Smith P, Brook C, Mowat AP 1986 Serum antigens of the amino-terminal propeptide of type III procollagen (PIII-P) - a biochemical marker of growth. Proceedings of the Xth Meeting of the Federation of European Connective Tissue Societies, Manchester, England

18. Underwood LE, Fischer DA, Frasier SD, Gertner JM, Kaplan SC, Kirkland RT, Lippe BM, Raiti S 1985 Degenerative neurologic disease in patients formerly treated with human growth hormone. J Pediatr 107:10-12

19. Marshall WA, Tanner JM 1969 Variations in the pattern of pubertal changes in girls. Arch Dis Child 44:291

20. Marshall WA, Tanner JM 1969 Variations in the pattern of pubertal changes in boys. Arch Dis Child 45:13

21. Bierich JR 1983 Stunted growth. Monatsschr Kinderheilkd 131:180-192

22. Tanner JM, Whitehouse RH, Takaishi M 1966 Standards from birth to maturity for height, weight, height velocity, and weight velocity: British children, 1965, part II. Arch Dis Child 41:613

22a. Greulich WW, Pyle SI 1959 Radiographic Atlas of Skeletal Development of the Hand and Wrist. Stanford University Press, Stanford

23. Hahn EG 1984 Blood analysis for liver fibrosis. J Hepatol 1:67-73

24. Quabbe HJ 1969 Radioimmunologische Bestimmung von Wachstumshormon 
im Plasma des Menschen. Z Klin Chem 7:259-268

25. Nie HN, Hull CH, Jenkins JG, Steinbrenner K, Bent DH 1975 SPSSStatistical Package for the Social Sciences. McGraw-Hill Book Company, New York

26. Becker J, Schuppan D, Benzian H, Bals T, Hahn EG, Cantaluppi C, Reichar P 1986 Immunohistochemical distribution of collagens type IV, V, VI and of procollagens types I and III in human alveolar bone and dentin. J Histochem Cytochem 34:1417-1430

27. Verde GG, Santi I, Chiodini P, Cozzi R, Dallabonzana D, Oppizi G, Liuzzi A 1986 Serum type III procollagen propeptide levels in acromegalic patients. J Clin Endocrinol Metab 63:1406-1410

28. Simon LS, Krane SM, Wortman PD, Krane IM, Kovitz KL 1984 Serum levels of type I and III procollagen fragments in Pagets disease of the bone. J Clin
Endocrinol Metabol 58:110-120

29. Brook C, Mürset G, Zachmann M, Prader A 1974 Growth in children with 45,XO Turner's syndrome. Arch Dis Child 49:789-795

30. Rosenfeld RG, Hintz RL, Johanson AJ, Brasel JA Burstein S, Chernausek SD, Clabots T, Frane J, Gotlin RW, Kuntze J, Lippe BM, Mahoney PC, Moore WV, New MI, Saenger P, Stoner E, Sybert V 1986 Methionyl human growth hormone and oxandrolone in Turner syndrome: preliminary results of a prospective trial. J Pediatr 109:936-943

31. Carey DE, Goldberg B, Ratzan SK, Rubin KR, Rowe DW 1985 Radioimmunoassay for type I procollagen in growth-hormone-deficient children before and during treatment with growth hormone. Pediatr Res 19:8-11

32. Job JC, Lambertz J, Sizonenko PC, Rossier A 1970 La croissance des enfants atteints de craniopharyngiome. Arch Fr Pediatr 27:341-353 